811.163.41'373.7

https://doi.org/10.18485/sj.2018.23.1.20

АНА Б. ПЕЈАНОВИЪ ${ }^{*}$

Универзитет Црне Горе

Филолошки факултет (Никшић)
Оригинални научни рад

Примљен: 04. 01. 2018.

Прихваћен: 29. 01. 2018.

\title{
О ЈЕДНОМ ТИПУ СИНТАКСИЧКИХ ФРАЗЕОЛОГИЗАМА
}

У раду се разматра статус једне врсте фразеолошких јединица које имају превасходно комуникативну функцију. За разлику од лексичких фразеологизама, ове фразеолошке јединице немају денотативно (сигнификативно) значење већ само модално. Њихов прагматички садржај састоји се у означавању односа говорника према ситуацији или саговорнику, као и у изражавању одричног/потврдног одговора. Од лексичких фразеологизама разликује их и реченична структура, због чега се називају синтаксички фразеологизми.

У савременој литератури фразеолошке јединице које су предмет наше пажње именују се као комуникеме, чиме се експлицитно изражава њихова функција.

У ове фразеолошке јединице спадају различити типови фразеологизама које смо раније издвојили као узречице [Пејановић 2010], као и друге, које ће бити предмет овог рада: Таман посла! Мало сутра! Како да не! (изрази који означавају категоричан одричан одговор).

Кључне ријечи: синтаксички фразеологизми/комуникеме, комуникативна функција, дијалошки дискурс, модалност, експресивност, одричност/потврдност.

"apejanovic@rambler.ru 
0.1. Упркос томе што фразеологија постоји већ 70 година као самостална језичка дисциплина, још увијек нису усаглашени ставови истраживача који се тичу обима и граница поменуте науке. Истраживачи који се баве фразеологијом нису сагласни ни када је у питању класификација језичких јединица које су њен предмет. Дискусиона питања око ширег или ужег схватања фразеологије покушали смо да превазиђемо својом класификацијом која узима у обзир не само категоријална својства и формално устројство ових јединица већ прије свега функционални аспект. Фунционални аспекат незаобилазан је критеријум класификације језичких јединица, па нас је то, уз остале критеријуме, руководило да фразеолошки фонд српског језика разврстамо на осам фразеолошких жанрова: сталне епитете, устаљена поређења, идиоме, клетве, заклетве, узречице, пословице и изреке [Пејановић 2010].

0.2. Да је функционални критеријум класификације као водећи оправдан, показују и новија фразеолошка истраживања усмјерена на комуникативни аспекат ових језичких јединица у чијем центру пажње су се нашли синтаксички фразеологизми. До сада су, наиме, у фокусу фразеолога углавном били лексички фразеологизми. Још је Б.А. Ларин, иако не сасвим досљедно, фразеологизме дијелио на лексическе и синтаксичке [Ларин 1956]. Д.Н. Шмељов скренуо је пажњу да у руском језику постоји низ фразеологизама који нису настали трансформацијом фразеолошких синтагми већ су резултат својеврсне лексикализације појединачних синтаксичких конструкција које имају фразеолошки карактер. Научник синтаксичку фразеологију дефинише као „везану синтаксу” и уводи термин „синтаксички везане конструкције-фразеосхеме” [Шмелев 2014: 327].

Важна разлика између лексичких и синтаксичких фразеологизама јесте другачији механизам формирања фразеолошког значења. Фразеологизација лексичких фразеологизама остварује се преосмишљавањем значења компоненти које улазе у њихов састав [Мршевић-Радовић 1987], док код синтаксичких фразеологизама долази до уопштавања семантике читаве полазне синтаксичке конструкције. По формалном устројству синтаксички фразеологизми имају реченичну структуру, али они представљају посебан вид реченица, чија се предикативност остварује неграматичким средствима. Њихова је главна функција комуникативна. Овдје би требало напоменути да постоји и одређени број лексичких фразеологизама који имају структуру реченице, али они, као и остали лексички фразеологизми, имају номинативну функцију, метафорично значење и сликовитост, која је карактеристика већине фразеолошких јединица. Већина лексичких фразеологизама може се замијенити ријечју идентификатором (кад на врби роди грожђе = никад). Лексички фразеологизми, као и ријечи, знак су денотата, имају одређено номинативно значење, уклапају се у контекст реченице и врше у њој одређену синтаксичку функцију. С друге стране, синтаксички фразеологизми функционишу самостално, што значи 
да немају функцију реченичног члана, већ у дискурсу наступају као комуникативне једнице са заокруженом семантиком, комуникативним циљем и прагматичким садржајем.

1. Синтаксички фразеологизми су универзална и продуктивна језичка појава. У сваком језику постоје конструкције којима се директно изражавају емоције, реакције и ставови. Синтаксички фразеологизми се употребљавају у разговорном језику, служе као реплика у дијалошкој комуникацији за изражавање потврдног или одричног одговора и читаве скале емоција, реакција и оцјена: слагање, неслагање, чуђење, дивљење, страх, сумња, невјерица, радост, осуда, иронија и сл. [Меликян 2001, Меликян 2014]. У русистичкој литератури језичке јединице о којима је ријеч именују се различито: као фраземи, синтаксички фразеологизми, сложени узвици [Емирова 1988, Телия 1995]. Ове комуникативне и експресивне језичке јединице имају сљедеће особине: 1) користе се у разговорном језику и у тијесној су вези са контекстом или конситуацијом; 2) имају само модално значење - изражавају однос према ситуацији или саговорнику, што значи да немају номинативно (денотативно) значење попут ријечи и синтагми, док се предикативност ових реченица исказује посебном интонацијом и цијелим садржајем. В.Ј. Меликјан комуникему дефинише као: „комуникативну непредикативну синтаксичку јединицу нерашчлањиву граматички, са модусном пропозицијом, која изражава одређени непојмовни смисаони садржај и служи као реакција на различите факте објективне стварности а у језику врши прагматичку функцију" [Меликян 2014: 87]. По његовом мишљењу, све комуникативне јединице имају значење, али се оно формира на различитим основама. Код неких се значење формира на основу номинативних значења ријечи, код других оно изражава психоемоционалну сферу човјекове дјелатности. Ове друге комуникативне јединице изражавају апстрактно значење (афирмативан/негативан одговор, позитивну/негативну оцјену и сл.), без строге диференцијације и ослонца на номинативно значење језичких јединица које су у њиховом саставу [Меликян 2014: 89].

2. Предмет наше пажње у овом раду биће само они синтаксички фразеологизми који изражавају категоричан негативан одговор у српском језику. На нашем списку, који не претендује на коначност, за сада се налазе сљедеће комуникативне јединице: Таман посла! Мало сјутра (мало морген)! Не пада ми на памет! Само преко мене мртва (мртве)! Тај филм нећеш гледати! Боже сачувај (Боже сабрани, Боже саклони)! Ни дао Бог! Ни случајно! Ни за живу главу! Ни за жива Бога! Ни за сва блага! Јеси ли ти критен (Јеси ли ти нормалан)! Нисам се јуче родила! Нисам од јуче! Нашао си будалу! Како да не! Не долази у обзир! Нема шансе (нема теорије)! За разлику од набројаних јединица, за изражавање потврдног одговора издвојили смо само сљедеће синтаксичке фразеологизме: Како да не! Него шта! Нема проблема! Није проблем! Нема фрке! Набројане комуникативне језичке јединице изражавају потврдан одговор 
уз виши или нижи степен увјерености. Као што се да примијетити, много је дужи списак комуникативних језичких јединица које експресивно изражавају категоричан одричан одговор у спрези са различитим емоцијама и ставовима говорника, као што су иронија, љутња, бијес и сл. Оцјењивачке комуникеме које изражавају позитиван став: Свака част! Алал 〈ти, му јој〉 вјера! E то се броји!, равнодушан став или изненађење: Па шта! Врло важно!, неслагање: Ма немој! Ма шта кажеш (причаш)! Не причај!, овом приликом такође остају ван разматрања и предмет су посебног рада.

И површним увидом у наведени списак синтаксичких фразеологизама изворни говорник (носилац језика) може потврдити да су све набројане јединице вишекомпонентне, да су устаљене и да се налазе готове у инвентару српског језика (репродуктивност), да је њихово значење цјеловито и не изводи се из суме значења појединачних компоненти (идиоматичност), да имају наглашену експресивност. Све наведене карактеристике које се сматрају диференцијалним особинама фразеолошких јединица присутне су и код напријед набројаних синтаксичких фразеологизама који изражавају одричан одговор. Заједничко за све набројане језичке јединице јесте и чињеница да се користе у дијалошком дискурсу за изражавање негативаног одговора, праћеног вишим или нижим степеном категоричности.

3. Наша даља анализа показаће разлике међу набројаним синтаксичким фразеологизмима - по структури, могућности варирања компоненти, могућности постојања и/или реконструкције прототипа, односно изворне мотивационе синтаксичке конструкције (унутрашње форме). Већ смо поменули да су наведене језичке јединице које имају структуру реченице нерашчлањиве. И то је, по нашем мишљењу, ван дискусије. Јасно је да се ни једна од ових реченица не може анализирати са аспекта чланова реченице из простог разлога што су компоненте које улазе у њихов састав, неке мање, неке више, а неке потпуно десемантизоване. Стога читава реченица има јединствено глобално значење одричности (јер се обавезно користи у дијалошком дискурсу као реплика), уз нижи или виши степен категоричности и различитих емоционално-експресивних конотација: изненађења, незадовољства, разочарења, љутње, бијеса и сл. Поједине јединице због свог синкретизма садрже додатне елементе значења који се појављују приликом актуализације прототипа на основу којег су настале.

Питање предикативности комуникема изазива неслагања и дискусије истраживача. Њихова већ поменута нерашчлањивост поједине научнике и то врло ауторитативне (Виноградов, Смирницки, Бабајцева, Меликјан) инспирисала је да тврде да наведене јединице нису предикативне. С друге стране, Лекант, Формановска, Балакај, Матавосјан износе супротан став, са којим се и ми слажемо [Меликян 2014: 98-99]. Ми сматрамо да је нерашчлањивост реченица посљедица идиоматизације значења, због чега се ове језичке јединице 
могу сврстати у фразеолошке ресурсе језика, али, с друге стране, ове комуникативне јединице посједују и предикативност јер у супротном не би ни биле реченице. Међутим, оне су посебне реченице и, по нашем мишљењу, њихова је предикативност само другачије изражена од „уобичајених реченица”, и то неграматичким средствима. Предикативност се код ових језичких јединица изражава специјалном (узвичном) интонацијом и додатним средствима која је прате. У највећем броју случајева та експресивност заснована је на иронији. Као што се може видјети, све наведене језичке јединце записане су са узвичником, а познато је да узвична интонација може бити један од начина изражавања предикативности. Можемо ли тврдити да синтаксичка јединица: Пожар! нема предикативност? По нашем мишљењу, и синтаксички фразеологизми на исти такав начин остварују предикативност, другим ријечима: објективна модалност у овом типу нестандардних реченица остварује се неграматичким средствима, односно узвичном интонацијом.

4. Устаљеност ових јединица такође је несумњива, она се, наравно, не схвата као апсолутна непромјењивост компонентног састава синтаксичких фразеологизама већ као релативна устаљеност облика и значења при којој глобално значење израза остаје исто. Уосталом, у фразеологији је одавно образложен став да се устаљеност фразеолошких јединица дефинише као релативана устаљеност облика и значења у оквиру структурно-семантичког модела дате фразеолошке јединице, при којој остаје препознатљив инваријант фразеолошке јединице [Мокиенко 1980]. Неки од синтаксичких фразеологизама су, попут сраслица, посвједочени само у једном облику без могућности варирања. Са списка наших комуникема такве су: Таман посла! Не долази у обзир! Тај филм нећеш гледати! Све три наведене фразеолошке јединице користе се увијек само у овом облику и замјена компоненти у њиховом саставу није могућа јер би у противном изазвала њихов распад.

Варијантност фразеолошких јединица неоспорна је чињеница. Да је она присутна и код овога вида фразеолгизама показују нам примјери комуникема који садрже факултативне варијанте: Како 〈да не! Наведени примјер илуструје случај синтаксичког фразеологизма који се може користити са компонентом $\partial a$ или или без компоненте $\partial a$ без икаквог утицаја на промјену глобалног значења израза. Варирање се остварује код појединих синтаксичких фразеологизама и замјеном компоненти у њиховом саставу. Такво лексичко варирање компоненти илуструјемо на примјеру комуникема Мало сутра! и њене варијанте Мало морген! или Нема шансе! и њене варијанте Нема теорије! Јасно је да замјена компоненти сутра са морген и шанса са теорија не доводе до промјене глобалног значења фразеолошке јединице. Као и код лексичких фразеологизама, у појединим комуникемама примијетно је и морфолошко варирање. За такав вид варирања наводимо примјере: Само преко мене мртва (мртве)! гдје се варира одређени и неодређени вид придјева: мртвог (мрт- 
ва), или род придјева: мртва (мртве). Међу синтаксичким фразеологизмима има и оних који настају по истом структурно-семантичком моделу, у који се на основу глобалног значења израза може сврстати више јединица. Такви су: Ни случајно! Ни за живу главу! Ни за жива Бога! Ни за сва блага! Све четири наведене јединице са интензификаторском функцијом спадају у исти структурно-семантички модел који би се могао описати значењем (нећу) + ни +за 'нешто најдрагоцјеније' јер компоненте које се варирају имају заједничку сему 'нешто најдрагоцјеније'. Појава варијантности само је још једна од уобичајених особина фразеолошких јединица и нипошто не доводи у питање устаљеност ових језичких јединица.

5. Иако вишезначност фразеолошких јединица није развијена као код лексике, она је присутна и код одређеног броја ових фразеологизама. Наша анализа показује да и синтаксички фразеологизми као поједини лексички фразеологизми могу бити полисемични. Са нашег списка у такве спадају изрази мало сутра! и сачувај Боже! Осим значења које остварују као синтаксички фразеологизми за исказивање категоричног одбијања, први израз може имати и лексичко значење 'никад', о чему је писао Милош Ковачевић у чланку Експресивност адинатонских конструкција у српском језику. Различита функција и природа израза може се прослиједити из примјера̂ употребе гдје се види да се он у појединим случајевима реализује у адвербијалној синтаксичкој функцији и има значење 'никад', док се у другим примјерима остврује као самостална експресивна комуникативна јединица са глобалним значењем 'нипошто, немогуће је, неоствариво је'. Уосталом, и сам аутор то примјећује кад каже да: „адинатонске конструкције, и синтагматске и реченичне, како смо видјели, најчешће имају значење универзалног временског одричног квантификатора 'никад', тј. означавају да се нешто ни у једном времену не може догодити јер је његова реализација условљена немогућим па самим тим и неостварљивим условом". Ковачевић даље запажа да: „са значењем 'никад' често интерферира значење 'никако'. Друкчије речено, оно што није остварљиво ни у једном времену истовремено се може тумачити да није остврљиво ни на који начин. Значење временског универзалног квантификатора 'никад' у одређеним контекстима може да имплицира значење начинског универзалног квантификатора 'никако', тако да се поједини примјери могу тумачити као адинатонски амбигвални, као примјери који се могу схватити са универзалним одричним како временским тако и начинским значењем". Даље се наводе примјери двозначности употребе израза, за које Ковачевић с правом констатује да су настали као посљедица полисемичности појединих фразеологизама [Ковачевић 2016: 192-193]. Ковачевићева напомена тачно описује синкретизам наведеног значења израза, ми бисмо кратко поновили: никад и нипошто. По нашем мишљењу, управо то синкретично значење немогућности и одричности (временске и начинске) пресудно је допринијело појави комуникативне функције фразеолошке једини- 
це. Да је првобитно значење наведеног фразеологизма проистекло из његове комуникативне употребе, свједочи нам и његова рјечничка дефиниција, која истовремено може бити корисна и за реконструкцију етимологије и настанка израза. У (шестотомном) Речнику Матице српске записан је израз мало сут$p a$ ! са обликом мало као факултативном компонентом, а једина илустрација употребе је управо без поменутог прилога мало:

(мало) сутра! фам. и ир. као узвик кад се нешто одбија, одриче, кад се не верује у нешто; - Ово је поп! Викну један од погађача и лупи по једној карти. - Сутра! узвикну онај што разбацује [карте], изврте карту, кад оно дама Глиш. [Речник MC/MX 1976 VI: 107].

Наведена рјечничка дефиниција израза, која га квалификује као узвик, као и стилистички квалификатори фамилијарно и иронично потврђују његову сферу употребе и прагматички садржај. Несумњиво је да се он првобитно користио у дијалогу као одричан одговор. Такође је јасно да се овај израз употребљавао као ироничан одговор у ситуацијама сличним наведеној.

И новији фразеолошки рјечници наведени израз биљеже и адекватно дефинишу. У Фразеолошком речнику српског језика Ђорђе Оташевић оправдано напомиње уз фиксацију израза: Мало сутра (морген) (обично у дијалошкој ситуацији) не долази у обзир, никако није могуће, уопште није тако, сигурно се неће догодити [Оташевић 2012: 697]. И у новом Хрватско-руском фразеолошком рјечнику записани су и преведени адекватним фразеолошким кореспондентима многи синтаксички фразеологизми укључујући и поменути: никаким образом, ни в коем случае, даже и не говори (не думай) [Menac i dr. 2011: 167$]^{1}$. Доље наведени примјери употребе из дневних и недјељних новина, као и са интернет извора, свједоче о његовој вишезначности и синкретичном карактеру семантике која је и проузроковала ту особину:

Боље сутра - мало сутра. Док моје вршњаке широм развијених земаља свијета подстичу и потичу да буду бољи, бржи, љепши.

Поглавље 35 - и Косово и Европа, мало сутра.

Субвенције одмах, радна места мало сутра.

У НАТО ћете ући мало сутра, џаба вам све рекламе...

Синдикат ће протествовати мало сутра. Број оних који свакодневно остају без посла у Републици Српској значајно је већи...

Мало сутра - убиства и пљачке се дешавају као и увек. Борба против тероризма?

Мало морген - терористи су углавом плаћеници...

Нека Амери овакав лет изведу са својим авионима, мало сутра.

,[...] Са овим платама кредити мало сутра, а ми нисмо ништа тужније приче него ови са Ендокрине. Из САД се доноси предлог новог устава Федераџије БиХ за који се тврди да тобоже нема никакве везе са Републиком Српском. Мало сутра" - нагласио је Влајки.

...нама лову па ћемо вам ми вратити сутра илити мало сутра...

\footnotetext{
${ }^{1}$ Када је у питању фиксација синтаксичких фразеологизама, може се констатовати да, за разлику од наших старијих фразеолошких рјечника [Матешић 1982], нова лексикографска издања биљеже многе од анализираних језичких јединица [Menac i dr. 2011; уп. Оташевић 2012].
} 


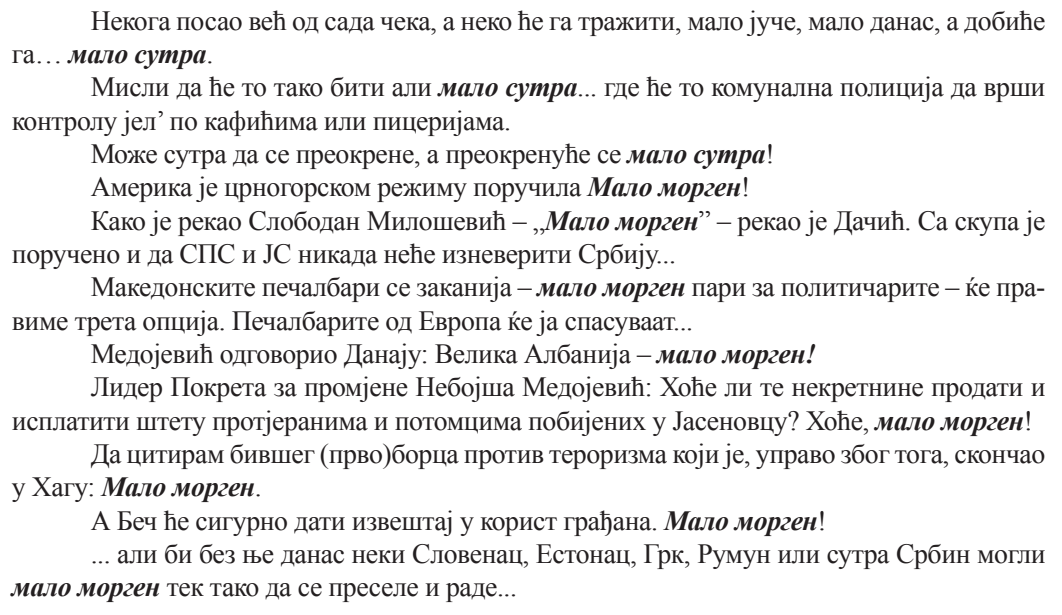

Још један синтаксички фазеологизам са нашег списка карактерише вишезначност. Ову особину фразеолошке јединице Боже сачувај (саклони, заклони, сахрани)! Ђорђе Оташевић правилно је записао и у дефиницији диференцирао три његова значења, као и неколико варијаната израза са компонентом теонимом:: ни дај Боже, ни за жива (живога, милога) Бога! Према овом рјечнику, посљедњи набројани су полисемични. Прво значење: при зграњавању због нечег непријатног, тужног. Друго: у (сујевјерном) страху, при отклањању неке непријатне помисли. И њихово треће значење: при појачаном одбијању [Оташевић 2012: 68-69].

6. За разлику од два наведена синтаксичка фразеологизма, наредни израз који се у српском језику користи у значењу категоричног негативног одговора једнозначан је. Његове рјечничке дефиниције дају адекватну семантизацију, а из прве наведене можемо се освједочити да се ради о наглашеном негирању:

таман посла! то никако, никако не. - Још ми то треба!... Таман посла! Моск [Речник MC/MX 1971 IV: 736].

Таман посла! Никако, нипошто, не долази у обзир [Оташевић 2012: 697].

Да израз Таман посла! има само једно значење, чиме се разликује од два раније анализирана, види се из дољенаведених примјера употребе овог синтаксичког фразеологизма. Увид у примјере показује да је израз досљедно, у свим случајевима, записан са узвичником. Из тога се може закључити да је његова контекстуална употреба недвосмислено везана за дијалог у којем се он користи као одговор-реплика којом се исказује категоричко негирање чињеница, стања, радњи, тј. околности које су предмет разговора: 
Нагодба, таман посла! То је апсолутна неистина. Очито се ради о злонамерно пласираним гласинама. За ове три године никада нисам писао ДОС-у, а најмање потребе за то имам сада - каже за „Новости” Млађан Динкић.

Ма какав пораз, таман посла! Док год је миграната, Мадам Меркел ће бити Канцелар! Али... ако понестане миграната... е онда може бити свашта.

„Једном је мајка мог пријатеља хтела да превезе кауч у други стан, и замолила је сина да телефонира власнику фирме за селидбе и пита јесу ли њихови носачи озбиљни, да можда не псују и како се понашају”, прича Андреј Васиљев. „Таман посла, младићу”, одговорио му је власник. „Сви наши носачи су факултетски образовани!”

Таман посла! Која је опет то будала? - Богме, паметан критичар, таман према Бекићевој науци! - Који је? - Бекићка! - Његова жена? - Разуме се [Домановић, Мртво море].

... А да парох пароха тужи и тужака епископу, - наставља домаћин, - и да то још парохијани знају!... Таман посла! Не знаш ко прође горе: тужитељ или тужени... [Сремаи, Поп Tupa u non Cnupa].

7. У српском, као и у свим језицима, постоји већи број синтаксичких фразеологизама. По својој структури, значењу и поријеклу они су разнородни. За разлику од лексичких фразеологизама, који имају одређени појмовни садржај, односно денотативно значење, те стога и у реченици имају функцију неког реченичног члана, синтаксички фразеологизми имају само модално значење. Њихово прагматичко значење одраз је субјективне модалности: односа адресата према ситуацији или адресанту. С обзиром на чињеницу да немају денотативно значење, у реченици синтаксички фразеологизми немају ни синтаксичку функцију већ се понашају као уметнуте ријечи или реченице или служе као реплика у дијалогу.

Комуникеме којима се изражава категоричан негативан одговор разнолике су и бројне (наш списак са почетка рада не претендује на коначност). Синтаксички фразеологизми са списка представљају готове у језику, устаљене, фреквентне и експресивне језичке јединице које се користе у дијалошкој ситуацији као реплика којом саговорник категорички негира одређене факте или околности. Заједничка особина свих синтаксичких фразеологизама јесте сфера употребе везана за разговорни стил у коме се остварује принцип језичке економије, који је и један од узрочника настанка ових специфичних фразеологизама. Друга важна особина синтаксичких фразеологизама је њихова реченична структура којом се диференцирају од лексичких фразеологизама. Структура нерашчлањиве реченице која има глобално значење негације, уз виши или нижи степен категоричности, у конкретним контекстуалним условима придобија додатну конотацију која се реализује у субјективној модалности као: негодовање, неслагање, протест, љутња, бијес и сл. 


\section{ИЗВОРИ И ЛИТЕРАТУРА}

Ковачевић 2016: Милош Ковачевић, „Експресивност адинатонских конструкција у српском језику". Научни састанак слависта у Вукове дане (Београд, 17-20. IX 2015). [Књ.] 45/1: [...] Експресивност у српском језику. Београд, 187-201.

Ларин 1956: Б.А. Ларин, Очерки по лексикологии, фразеологии и стилистике. Ленинград.

Меликян 2001: В.Ю. Меликян, Словарь: Эмочионально-экспрессивные обороты живой речи, Москва: Флинта. Наука.

Меликян 2014: В.Ю. Меликян, Современный русский язык: синтаксическая фразеология, Москва: Флинта, Наука.

Матешић 1982: Josip Matešić, Frazeološki rječnik hrvatskoga ili srpskoga jezika. Zagreb: Školska knjiga.

Менац и др. 2011: Antica Menac, Željka Fink Arsovski, Irina Mironova Blažina, Radomir Veenturin, Hrvatsko-ruski frazeološki rječnik. Zagreb: Školska knjiga.

Мокиенко 1980: В.М. Мокиенко, Славянская фразеология, Москва: Высшая школа.

Мршевић-Радовић 1987: Драгана Мршевић-Радовић, Фразеолошке глаголско-именичке синтагме у савременом српскохрватском језику, Београд: Филолошки факултет.

Оташевић 2012: Ђорђе Оташевић, Фразеолошки речник српског језика. Нови Сад: Прометеј.

Пејановић 2010: Ана Пејановић, Фразеологија Горског вијениа: фразеолошки жанрови, културни концепти, руски преводи. Подгорица: Црногорска академија наука и умјетности.

Речник MC/MX 1971 IV: Речник српскохрватскога књижевног језика. Књ. IV. Нови Сад.

Речник MC/MX 1976 VI: Речник српскохрватскога књижевног језика. Књ. VI. Нови Сад.

Телия 1995: В.Н. Телия, „Основные особенности значения идиом как единиц фразеологического состава языка". [У:] Т.С. Аристова, М.Л. Ковшова и др. Словарь образных выражений русского языка. Под ред. В.Н. Телия. Москва: Отечество, 10-16. 
Эмирова 1988: А.Н. Эмирова, Русская фразеология в коммуникативном аспекте. Ташкент: Фан.

Шмелев 1977: Д.Н. Шмелев, Современный русский язык. Лексика. Москва: Просвещение.

\section{ОБ ОДНОМ ТИПЕ СИНТАКСИЧЕСКИХ ФРАЗЕОЛОГИЗМОВ}

\section{Резюме}

В настоящей работе автором рассматривается статус одного типа фразеологических единиц с преимущественно коммуникативной функцией. В отличие от лексических фразеологизмов, у данных фразеологических единиц нет денотативного (сигнификативного) значения, а только модальное. Их прагматическое содержание состоит в выражении отношения говорящего к обстановке или участникам коммуникативного акта, а также в выражении отрицательного/утвердительного ответа. От лексических фразеологизмов их отличает структура предложения, а тажже коммуникативная функция. Поэтому данные языковые единицы и получили название синтаксичкие фразеологизмы.

Синтаксические фразеологизмы выражают прагматическое содержание разного рода, но предметом настоящей работы были только те единицы, которые выражают категорический отрицательный ответ в сербском языке. Как показал проведенный анализ, в сербском языке существуют разнообразные с точки зрения структуры конструкции, которые нерасчлененно выражают категорический отрицательный ответ. Рассмотренные синтаксические фразеологизмы обладают всеми признаками фразеологических единиц, такими как: воспроизводимость, устойчивость, экспрессивность, вариативность.

Ключевые слова: синтаксический фразеологизм/коммуникема, комуникативная функция, диалогический дискурс, модальность, экспрессивность, эмоциональность, оценка, интенсивность, категорический отрицательный ответ.

Анна Б. Пеянович 